\title{
On Becoming a Leadership Coach
}





\title{
On Becoming a Leadership Coach
}

\section{A Holistic Approach to Coaching Excellence}

\author{
Edited by \\ Christine Wahl, Clarice Scriber, \\ and Beth Bloomfield
}




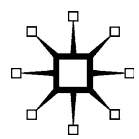

ON BECOMING A LEADERSHIP COACH

Copyright @ Christine Wahl, Clarice Scriber, and Beth Bloomfield, 2008.

Softcover reprint of the hardcover 1st edition 2008 978-0-230-60678-4

All rights reserved.

First published in 2008 by

PALGRAVE MACMILLAN®

in the US-a division of St. Martin's Press LLC,

175 Fifth Avenue, New York, NY 10010.

Where this book is distributed in the UK, Europe and the rest of the world, this is by Palgrave Macmillan, a division of Macmillan Publishers Limited, registered in England, company number 785998, of Houndmills, Basingstoke, Hampshire RG21 6XS.

Palgrave Macmillan is the global academic imprint of the above companies and has companies and representatives throughout the world.

Palgrave ${ }^{\circledR}$ and Macmillan ${ }^{\circledR}$ are registered trademarks in the United States, the United Kingdom, Europe and other countries.

ISBN 978-1-349-60340-4 ISBN 978-0-230-61431-4 (eBook)

DOI $10.1057 / 9780230614314$

Library of Congress Cataloging-in-Publication Data

On becoming a leadership coach : a holistic approach to coaching excellence / edited by : Christine Wahl, Clarice Scriber, and Beth Bloomfield.

p. $\mathrm{cm}$.

Includes bibliographical references and index.

1. Executives-Training of. 2. Executive coaching. 3. Leadership.

4. Employees-Coaching of. I. Wahl, Christine. II. Scriber, Clarice.

III. Bloomfield, Beth.

HD30.4.05 2008

$658.4^{\prime} 092-\mathrm{dc} 22$

A catalogue record for this book is available from the British Library.

Design by Newgen Imaging Systems (P) Ltd., Chennai, India.

First edition: August 2008

$\begin{array}{llllllllll}10 & 9 & 8 & 7 & 6 & 5 & 4 & 3 & 2 & 1\end{array}$

Transferred to Digital Printing in 2012 
To our students over the years in the Georgetown University Leadership Coaching Program, who have found their own unique leadership coaching voices through mastery and improvisation. 



\section{Contents}

List of Figures $\quad$ ix

List of Tables - xi

List of Templates xiii

Introduction $\quad \mathrm{xv}$

\section{Part I Being}

1 On Becoming a Leadership Coach 3

Neil Stroul and Christine M. Wahl

2 Sacred Space: Where Possibilities Abound and Change Is Engendered

Julie K. Shows and Clarice L. Scriber

3 Eastern Influence on Coaching $\quad 21$ Randy Chittum

4 Continued Development: Self-Authorship and Self-Mastery

Frank Ball

\section{Part II Doing}

5 In the Spirit of Coaching

Sheila Haji

6 G.R.A.C.E. at Work-Strong Relationships for Powerful Results Eric de Nijs

7 Using Story in Coaching

Margaret Echols, Karen Gravenstine, and Sandy Mobley

8 Whose Story Is This, Anyway? Identification with Clients in Leadership Coaching 
9 Congratulations-You're in Breakdown! Jennifer Sinek

10 The Role of Emotions in Coaching Randy Chittum

11 Using Somatics to Coach Leaders Margaret Echols and Sandy Mobley

12 Distinctions for Coaching Leaders Beth Bloomfield

\section{Part III Using}

$13 \mathrm{ALIFE}^{\mathrm{TM}}$ : A Listening Model for Coaching Christine M. Wahl and Neil Stroul

14 Coaching in Organizations Randy Chittum

15 Moving the Client Forward: Designing Effective Actions Frank Ball and Beth Bloomfield

16 Assessments for Insight, Learning, And Choice in Coaching Sue E. McLeod

17 Coaching and Leading as Stewards for Sustainability Lloyd Raines

18 The Thinking Path

Alexander Caillet

19 Executive Coaching for Leadership Development:

Five Questions to Guide Your Program Design

Sheryl D. Phillips and Frank Ball

20 Coaching for Leadership Presence

Clarice L. Scriber

21 Coaching for Leverage: Helping Clients to Manage

Priorities, Time, Energy, and Resources

Katherine Ebner

22 Action Learning: An Approach to Team Coaching Jennifer Whitcomb

23 Coaching New Teams

Patricia A. Mathews 


\section{Figures}

6.1 G.R.A.C.E. at work: Playing in a bigger space 44

$\begin{array}{ll}6.2 \text { G.R.A.C.E.: Full coaching checklist } & 50\end{array}$

7.1 A model for using story in coaching: SCAN 55

9.1 A formula for change $\quad 71$

$\begin{array}{ll}15.1 \text { The flow of coaching } & 120\end{array}$

$\begin{array}{lll}\text { 17.1 Four stewardship relationships } & 141\end{array}$

$\begin{array}{ll}18.1 \text { Thinking path framework } & 150\end{array}$

18.2 The current and desired states 159

$\begin{array}{ll}18.3 & \text { The action plan } \\ 161\end{array}$

$\begin{array}{ll}19.1 \text { The flow of coaching } & 171\end{array}$

$\begin{array}{ll}20.1 \text { Qualities that exhibit leadership presence } & 178\end{array}$

$\begin{array}{ll}21.1 \text { Leverage coaching framework } & 191\end{array}$

22.1 Components of action learning 200 



\section{Tables}

2.1 Leadership coaching survey: Qualities 13

$\begin{array}{ll}\text { 2.2 Leadership coaching survey: Practices } & 17\end{array}$

3.1 Eastern/Western thinking 22

$\begin{array}{lll}9.1 \text { Types of breakdown } & 72\end{array}$

$\begin{array}{lll}10.1 & \text { Emotional intelligence } & 78\end{array}$

$\begin{array}{llr}15.1 & \text { Steps to create self-observations } & 122\end{array}$

$\begin{array}{ll}15.2 & \text { Steps to create practices } \\ 123\end{array}$

$\begin{array}{ll}15.3 & \text { Steps to create an inquiry } \\ 15.4 & \text { Creating a }\end{array}$

$\begin{array}{ll}15.4 \text { Creating a structure of support } & 126\end{array}$

20.1 Questions to aid the client-leader's transformation 183

21.1 Priorities interview-Sample questions 191

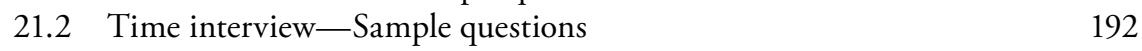

21.3 Energy interview-Sample questions 193

21.4 Resources interview-Sample questions 195 



\section{Templates}

18.1 The current state

18.2 A time when change occurred

18.3 The desired state 



\title{
Introduction
}

\author{
Christine M. Wahl
}

One way or another, we all have to find what best fosters the flowering of our humanity in this contemporary life, and dedicate ourselves to that.

-Joseph Campbell

ossibility. Sustainability. Agility. Reality. Opportunity. Quality. Authenticity.
Ability. Capacity. Stability. Productivity. Curiosity. Rationality. Emotionality.
Dignity. Humanity.

The meanings associated with this word list have tremendous connection to the work we do as leadership coaches. Coaching leaders is a heart-and-soul, mind-andbody endeavor. Such an endeavor focuses on results and requires clients to step on the challenging path of moving beyond one's current boundaries. Such work is uncomfortable, emboldening, freeing, and grounding. For surely, it brings leaders back to a person they know well-themselves.

So much of coaching leaders is about helping them remember their best version of "self." We call this authenticity. We need more of it from our leaders.

The chapters in On Becoming a Leadership Coach: A Holistic Approach to Coaching Excellence are written by coaches and educators who have been on the faculty of the Leadership Coaching Certificate Program at Georgetown University. The writings cover topics that reflect heart and soul, mind and body. Our intention in writing this book, divided into major sections of "Being," "Doing," and "Using," is to share our current thinking in multiple domains of leadership coaching. While aimed primarily at helping coaches stay in their own development and giving coaches concepts and tools to work with, this book speaks also to leaders, managers, educators, consultants, psychologists, clergy, and entrepreneurs. The concepts presented here apply to development and thereby help anyone wishing to understand themselves better find greater fulfillment in their personal lives and create more productive work lives.

In this book, you will find chapters on what it means to "be" a coach, what coaches "do," and tools that coaches "use." The act of coaching leaders is aimed at supporting them in producing sustainable results in the most humane way. Leaders 
create the future, they affect business, economics, global productivity, efficiency, and sustainability, and they do this through the "who" that they embody daily. Their "who" touches and influences all the people in their orbit, both near and far. It is from their "who" that their actions flow, and from their actions, they work to achieve results that will benefit the whole-their organizations and, ultimately, the larger systems within which they live.

As coaches, we have been influenced by many who came before us and wish to thank each of the big thinkers we have learned from. While there are too many to mention here, we are grateful to all of those teachers who have been in our lives, either by reading their work or experiencing their teaching in real-time, who have challenged our thinking and supported our humanness in ways big and small. We are grateful to all of our students, who over the past seven years, have stimulated fantastic conversations and helped us to continually refine our own processes. We are grateful to the deans and administrators who have known and supported us at Georgetown University. Lastly, we are grateful to our families, whose precious and generous support surely allows us to focus on our passion of creating more joy and life within organizations, through the courage of the leaders with whom we work.

As you read the following chapters, we hope you find inspiration and validation, and that your passion for excellence finds a new spark that continues to motivate. Every coach is an ambassador for bringing generosity, openness, curiosity, and kindness into the world of achieving in the workplace; coaching leaders brings these qualities of humanity to the foundation of doing business in today's world, with the mission of creating more and more ambassadors. May you be graced with time to reflect, support to engage in personal and professional renewal, and resolve to continue to make a difference in the lives — the "being alive" — of those you influence.

I don't believe people are looking for the meaning of life as much as they are looking for the experience of being alive. 